\title{
First Occurrence and Paleo-Ecological Implications of Insects (Orthoptera: Ensifera Gryllidae) in the Romualdo Member of the Santana Formation, Eo-Cretaceous of the Araripe Basin
}

\author{
LUÍS C.B. FREITAS ${ }^{1}$, GERALDO J.B. DE MOURA² ${ }^{2}$ and ANTÔNIO A.F. SARAIVA ${ }^{3}$
}

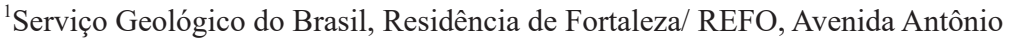 \\ Sales, 1418, Joaquim Távora, 60135-101 Fortaleza, CE, Brazil \\ ${ }^{2}$ Universidade Federal Rural de Pernambuco/ UFRPE, Departamento de Biologia, Laboratório de Estudos Herpetológicos \\ e Paleoherpetológicos, Rua Don Manuel de Medeiros, s/n, Dois Irmãos, 52171-900 Recife, PE, Brazil \\ ${ }^{3}$ Universidade Regional do Cariri, Laboratório de Paleontologia da URCA - L.P.U., \\ Rua Cel. Antônio Luiz, 1161E, Pimenta, 63100-000 Crato, CE, Brazil
}

Manuscript received on September 28, 2015; accepted for publication on November 27, 2015

\begin{abstract}
The Romualdo Member of the Santana Formation, a lithostatigraphic unit attributed to a marine intrusion, is famous for its preserved fossils in calcareous concretions, which stand out for their diversity and excellent preservation levels. This paper aims to record the first occurrence of the Class Insecta in the Romualdo Member of the Santana Formation of the Araripe Basin, as well as to describe and discuss the paleoecological implications of such finding. The first occurrence of the order Orthoptera (family Gryllidae) is presented for this unit. This new species is attributed to the genus Araripegryllus, that lasted throughout the deposition of the Crato Member, which is under the Romualdo Member. In reference to its statigraphic origin, the specimens was named Araripegryllus romualdoi sp. nov.
\end{abstract}

Key words: Araripegryllus, Grylloidea, Calcareous concretions, Araripegryllus romualdoi.

\section{INTRODUCTION}

The Romualdo Member, the upper unit in the Santana Formation, stands out for the quality and tridimensional preservation of its fossils in calcareous concretions, belonging to different taxonomic groups, such as Gymnosperms and Angiosperms leaves and trunks (Saraiva et al. 2003, Lima et al. 2012); Gastropods (Beurlen 1964); Crustaceans (Martins Neto 1987 and Pinheiro et al. 2013); Conchostracans (Carvalho and Viana 1993); Ostracods (Carmo et al. 2004)

Correspondence to: Luis Carlos Bastos Freitas

E-mail: lcgeologia@hotmail.com and, especially, vertebrates: Chondrichthyes Actinopterygii (Agassiz 1841, Brito and Ferreira 1989); Testudines (Hirayama 1998, Oliveira and Kellner 2005); Dinosauria (Kellner 1999, Kellner and Campos 1996, Martill et al. 1996, Naish et al. 2004); Pterosauria (Kellner 1984, Wellnhofer 1985, Kellner and Tomida 2000, Witton 2009, Bantim et al. 2014); and Crocodilia (Price 1959, Kellner 1987) and no insect has yet been attributed to this unit in the literature, which limits paleo-ecological inferences, since insects (especially Orthoptera) are excellent bioindicators of paleoenvironments (Martins Neto 2006). 
Orthopteran constitutes the most diverse group of Polyneoptera, containing around 22.5 thousand species (both extant and fossils) (Grimaldi and Engel 2005, Heads and Martins Neto 2007).

Until 2005, 61 orthopteran fossil species (Ensifera + Caelifera + Phasmatoptera) had been described for Brazil (22\% of the Brazilian paleoentomofauna), all for the Crato Member of the Santana Formation (Martins Neto 2005). Since then, no other Ensifera specimen has been described for the Santana Formation.

In view of the foregoing, this paper aims to record the first occurrence of the Class Insecta in the Romualdo Member of the Santana Formation of the Araripe Basin, as well as to describe and discuss the paleo-ecological implications of such finding.
The ZooBank Life Science Identifier (LSID) of this publication is: urn: 1sid:zoobank. org:pub:7D28D494-751D-45CC-872930731689C4B4

\section{MATERIALS AND METHODS}

The material under study comes from controlled excavations in the surroundings of the geological site known as Parque dos Pterossauros (Pterosaurs' Park), in the Araripe Geopark (24M 0420696 NO UTM 9205 958) (Figure 1), where the greenish calciferous shale of the Romualdo Member of the Santana Formation of the Araripe sedimentary basin (Northeastern Brazil). Such Aptian-Albian shales are rich in ostracods where there is an abundance of calcareous concretions (Figure 2),

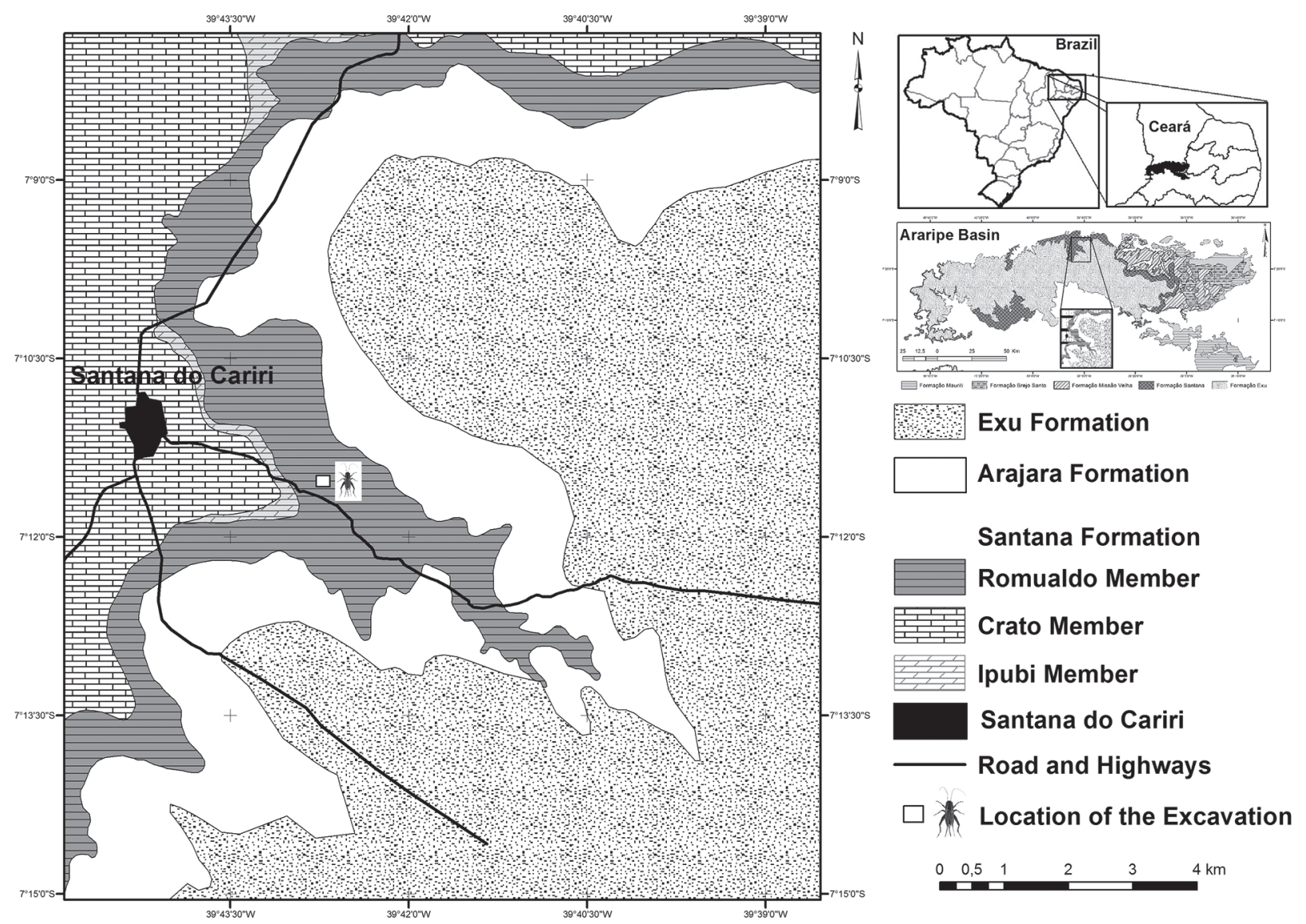

Figure 1 - Map of the location of the Santana do Cariri region within the Araripe sedimentary basin, highlighting the Romualdo Member and the location of the excavations. (Road and Highways - Location of the Excavation). 
often fossiliferous (Assine 1992, Saraiva et al. 2007, Fara et al. 2005, Vila Nova et al. 2011) and is internationally renowned for the tridimensional preservation of its fossils (Kellner 2002, Pinheiro et al. 2013).

The Santana Formation, of middle-upper Albian age (Maisey 1991, Berthou 1994, Boss and Veiga 2011) is currently outcropping, surrounding a large part of the geomorphological profile of the Araripe Plateau.
In order to study and compare the fossil samples, a comprehensive bibliographical review was carried out about the paleoentomofauna of the Santana Formation, using, for that, publications in indexed journals and classical literature relevant to the paleontology of this geological unit.

The material being studied is represented by a sample of calcareous concretion containing a fossil. The specimen was observed and photographed with binocular lenses and is kept at the paleontology

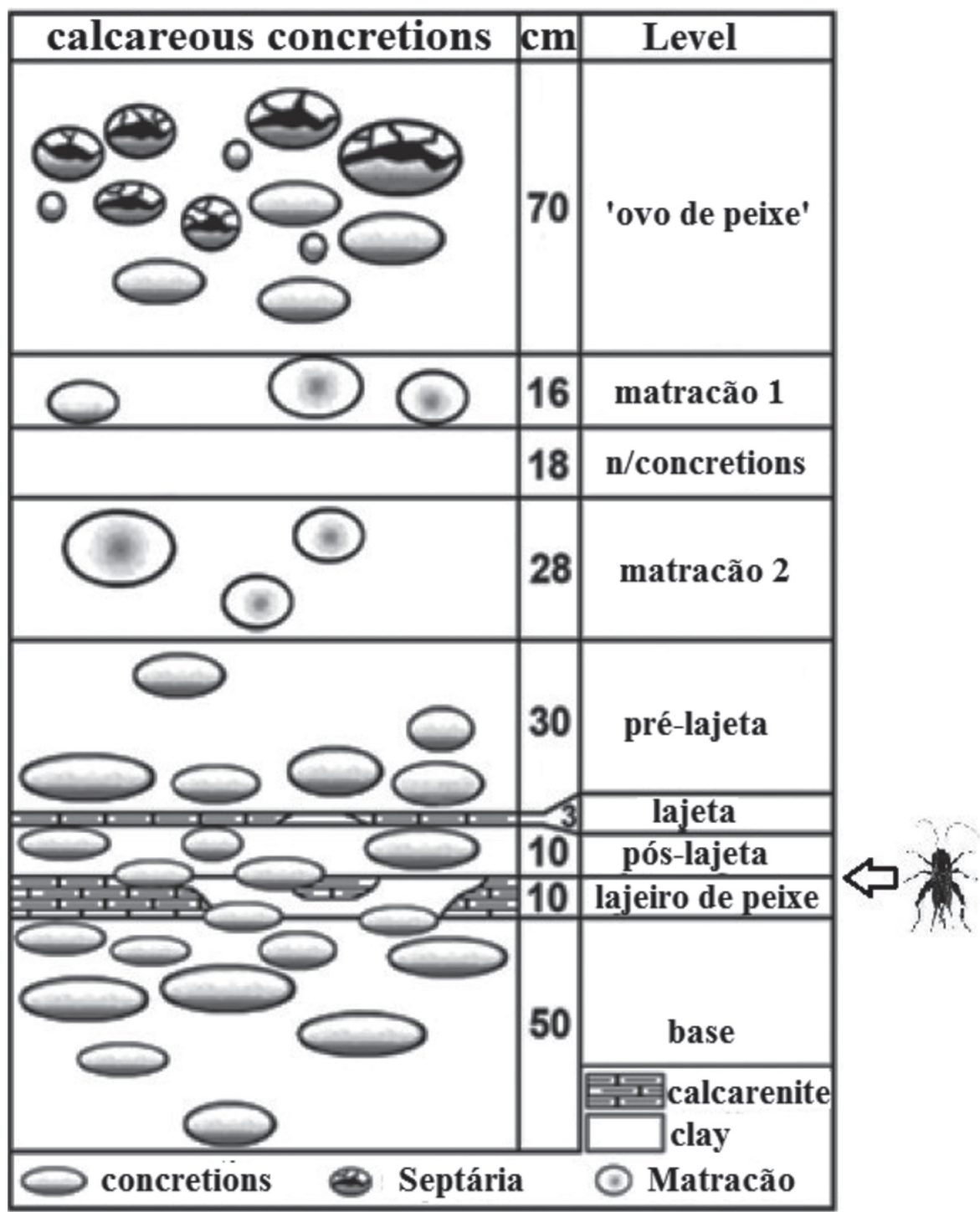

Figure 2 - Schematic profile of the distribution of the calcareous concretions and the location of the fossil finding, modified from Saraiva et al. 2007. 
collection of the URCA (Regional University of Cariri) Paleontology Museum in Satana do Cariri, under list number MPSC I846 p and cp, coming from the Romualdo Member.

\section{Systematic Paleontology}

Order Orthoptera Olivier 1789

Suborder Ensifera Chopard 1920

Family Gryllidae Laicharting 1781

Genus Araripegryllus Martins Neto 1987

Araripegryllus romualdoi sp. nov.

ZooBank Life Science Identififier (LSID) urn:1sid:zoobank.org:act:9D696FB1-FEF1-439DBABB-884394793A42

Etymology - romualdoi, in reference to its statigraphic origin, Romualdo Member of the Santana Formation.

Holotype - MPSC 1846p/MPSC 1846cp (Figure 3) Locality - Parque dos Pterossauros (Pterosaurs' Park) Geological site (Araripe Geopark), 3km from the seat of the city of Santana do Cariri, Ceará.
Horizon: Green shales, upper unit of the Santana Formation, Araripe Basin (lower Cretaceous).

Diagnosis:

Pronotum wider than the head, antennae coming from the center of the head, elongated cerci, robust femurs, non-elongated body and forewings with length over $5 \mathrm{~mm}$.

Description:

Body $10 \mathrm{~mm}$ long and $5 \mathrm{~mm}$ wide, $14 \mathrm{~mm}$ (body +forewings). The thorax is very robust. The head is a little smaller than the pronotum, $3 \mathrm{~mm}$ wide and $2 \mathrm{~mm}$ long. The antennae were not well preserved, and there is only a short filament on the left side, coming from about the center of the head. The hind legs femurs are robust and the cerci are elongated. The femur is $7 \mathrm{~mm}$ long and $3 \mathrm{~mm}$ wide (widest portion of the hind leg), and the front legs are $2.5 \mathrm{~mm}$ long and $1.2 \mathrm{~mm}$ wide. Front tibiae are also robust, measuring about $3 \mathrm{~mm}$ (Figure 3 ).

Some important features for species differentiation are absent or poorly preserved,

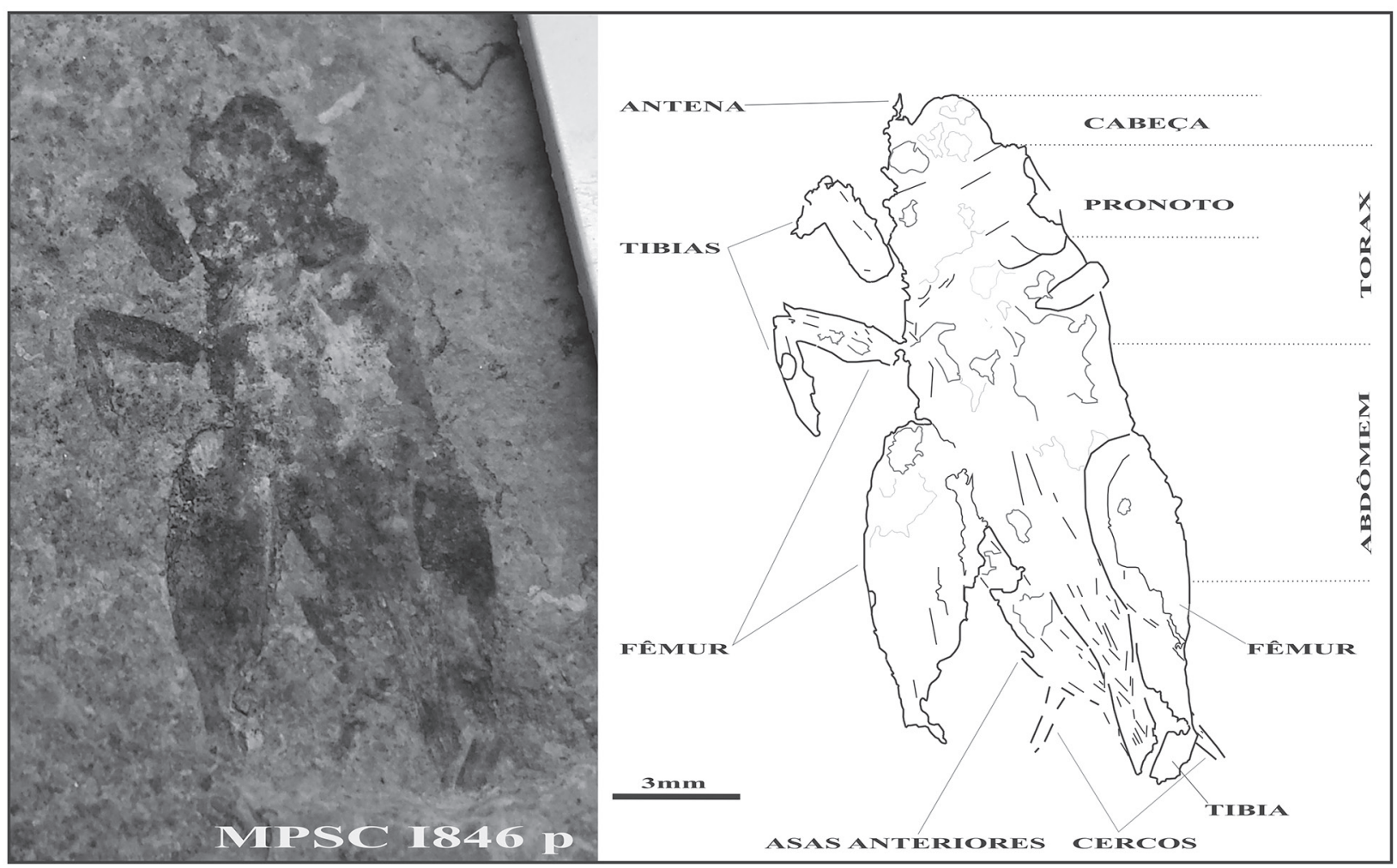

Figure 3 - Araripegryllus romualdoi sp. nov. (MPSC 1846p) on the left, and its schematic drawing on the right. 
such as tibiae, tarsi, wings and antennae. The presence of an ovipositor is not evident, being thus impossible to initially classify it as male or female with certainty. However, it has cerci with length over $5 \mathrm{~mm}$ and evident folded wings covering and exceeding the length of the body. The length of the forewings is greater than that of the body.

\section{DISCUSSION}

Most Cearagrillus (Baissogryllidae) species are individualized by their wing features, especially the shape of the speculum, chords and harps, which are not present in this specimen.

The legs have robust femurs, a distinct feature in Araripegryllus (Grillidae) and Cearagrillus, and a common feature in Gryllotalpidaes. However, the elongated cerci, usually turned into stridulatory devices, the head with smaller dimensions than the pronotum, and the non-elongated body (elongated bodies are also a noticeable Gryllotalpidae feature) allow us to place Araripegryllus romualdoi sp. nov. (MPSC 1846p) into the Gryllidae family. Another important taxonomic aspect is that the front tibiae are present in the specimen and are smooth, whereas in Gryllotalpidae they are covered with long spikes that are used for burrowing.

Cearagryllus are generally longer, reaching up to $32 \mathrm{~mm}$ of body length (C. perforatorius) and a relatively large head (with the exception of $C$. microcephalus, that is small-headed), males have a large stridulatory organ, and females have a long, spear-shaped ovipositor, with variable lengths.

The Gryllidae family is the main family in the Grylloidea superfamily, with over 350 existing genera, and over 3,000 species distributed worldwide (Rentz and Su 2003), and is comprised of four genera in the Santana Formation. Araripegryllus Martins Neto 1987 (7 spp.), Brontogryllus, Martins Neto 1991 (1 sp.), Cratogryllus Martins Neto 1991 (3 spp.) and Nanoararipegryllus, Martins Neto 2002 (1 sp.); gathering 12 species in the Gryllidae family.
In the Araripegryllus genus, according to Martins Neto (1991), the female has a long, spearshaped ovipositor, shorter than the cerci. The head is relatively large, globular, and bigger in width than in length; the antennae start from the middle of the head, a robust scape. A rectangular pronotum ranges from slightly to much larger than the head. Robust cerci, long abdomen, as the body's length. A robust femur, tibia with three apical spurs, tarsus with an extremely long first segment and the second being "heart-shaped". Forewings between 5 and $25 \mathrm{~mm}$ long, $10 \mathrm{~mm}$ wide and triangular, the base is larger than the apical area. The male has stridulatory organs: oval speculum.

The general features of the specimens (pronotum larger than the head, antennae coming out from the center of the head, elongated cerci, robust femur, non-elongated body, and forewings longer than $5 \mathrm{~mm}$ ) presented in the diagnosis, compared with the general features of the genus Araripegryllus, allow us to place them into this genus.

Comparing Araripegryllus romualdoi sp. nov. with other species in the genus, we can notice that the head of the analyzed specimen is relatively less thick than the pronotum and thorax, which is a constant feature of Araripegryllus (specially females), as well as the robust hind legs, with a length-width ratio greater than that of $A$. robustos (the specimen with the longest femur in the genus). The cerci, in the highlighted part, do not have spikes, which is by itself a difference from A. serrilhatus and brings it closer to $A$. femininus (with few spikes), but differs from the latter when it comes to size and thickness of the head and front and hind legs. The length of the femur is similar to others in the genus, such as A. nanus, although this one has short cerci. It is also worth mentioning that the length of the head corresponds to two thirds of its width, which differs from A. femininus.

From the features of the robust limbs, we can infer that the specimen had a great hopping ability 


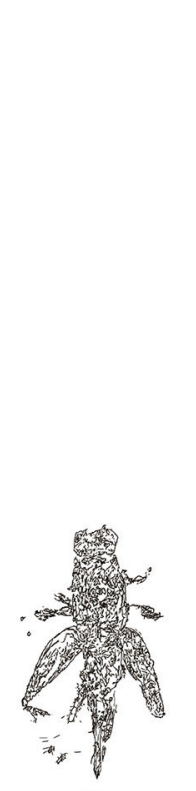

1
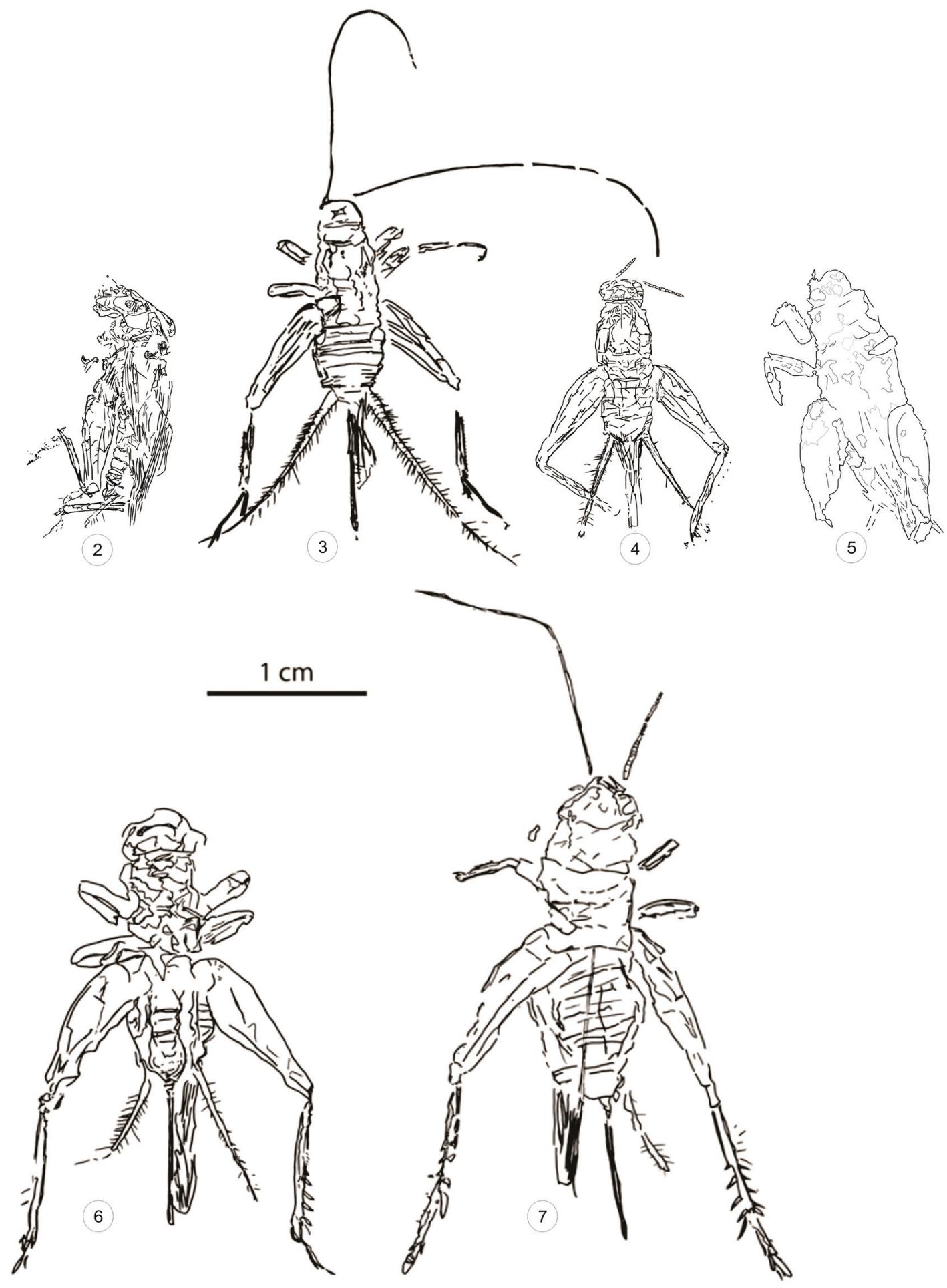

Figure 4 - Schematic drawings comparing the species - 1: Caririgryllus brachypterus, Martins Neto 2002; 2: Araripegryllus nanus, Martins Neto 1991; 3: Araripegryllus serrilhatus, Martins Neto 1991; 4: Araripegryllus femininus, Martins Neto 1991; 5: Araripegryllus romualdoi, sp. nov; 6 - 7: Araripegryllus robustos, Martins Neto 2002. Adapted from Martins Neto 1991 and Lee 2011. 
and probably lived near the ground, but was not a burrower such as Gryllotalpidae, since its legs were not used for burrowing, as they were not adapted to this function. A morphological comparison between the aforementioned species can be found in Figure 4.

The inclusion of some specimens in the genus Araripegryllus and Cearagrillus did not use all the criteria described as determining for the genera, containing some features that differ from the initial ones. Such as A. nanus, that has short cerci, whereas, in the general description of the genus, all should have long cerci. Or that not every species shows antennae coming out from the center of the head.

\section{CONCLUSIONS}

The morphological features shown by the specimen MPSC 1846 p allow us to identify it as a new species and classify it within the family Gryllidae; genus Araripegryllus. However, important parts in the differentiation of species of this taxon, such as wings, antennae and legs were not well preserved, making it difficult to reach a deeper diagnosis of the specimen. Nevertheless, the preserved diagnostic features allow us to place it within this family, and differentiate it from other species within the genus Araripegryllus, thus being a new species of this genus (Araripegryllus romualdoi sp. nov.). The record of an insect in the calcareous concretions of the Romualdo Member (first recorded occurrence) is the proof that species that are sensitive to climate changes, such as insects, endured such distinct geological and climatic events as the ones that led to the formation of the Crato and Romualdo Members of the Santana Formation. They also indicate, for the original area and stratum, little transport and proximity with the ground. The fossilization of an insect in a calcareous concretion is the proof that insects are also able to trigger chemical reactions that will form concretions around them, thus increasing the range of living beings that may have been fossilized in them, and are still to be found and studied.

\section{REFERENCES}

AGASSIZ L. 1841. On the fóssil fishes found by Mr. Gardner in the Province of Ceará, in the North of Brasil. Edinburgh new philosophical journal. Edinburgh 30: 80-84.

ASSINE ML. 1992. Análise Estratigráfica da Bacia do Araripe, Nordeste do Brasil Rev Bras Geociênc 22(3): 289-300.

BANTIM RAM, SARAIVA AAF, OLIVEIRA GR AND SAYÃO JM. 2014. "A new toothed pterosaur (Pterodactyloidea: Anhangueridae) from the Early Cretaceous Romualdo Formation, NE Brazil”. Zootaxa 3869(3): 201-223.

BERTHOU PY. 1994. Critical analysis of the main publications about the stratigraphical framework of the Paleozoic and Mesozoic sedimentary deposits in the Araripe Basin (northeastern Brazil). In: III Simpósio sobre o Cretáceo do Brasil, Boletim, p. 123-126.

BEURLEN K. 1964. As espécies dos cassiopinae, nova subfamília dos turritellidae, no Cretáceo do Brasil. Arq Geol, Recife 5: 1-44.

BOOS ADS AND VEIGA CS. 2011. Paleofauna de vertebrados registrada na Formação Santana (Cretáceo), Bacia do Araripe, nordeste do Brasil (Vertebrate paleofauna described for the Santana Formation (Cretaceous), Araripe Basin, northeast of Brazil). Acta Biol Par, Curitiba 40(34): 119-127.

BRITO PM AND FERREIRA PLN. 1989. First hibodont from Chapada do Araripe. An Acad Bras Cienc, Rio de Janeiro 61: 53-57.

CARMO DA, LAETRAFAEL RM, VILHENA RM AND TOMASSIC HZ. 2004. Redescription of Theriosynoecum silvai and Darwinula martinsi, Crato Member (Santana Formation), Lower Cretaceous, Araripe Basin, NE Brazil. Rev Bras Paleontol 7: 151-158.

CARVALHO IS AND VIANA MSS. 1993. Os conchostráceos da bacia do Araripe. An Acad Bras Cienc, Rio de Janeiro 65: 181-188.

FARA E, SARAIVA AAF, CAMPOS DA, MOREIRA JKR, SIEBRA DC AND KELLNER AWA. 2005. Controlled excavation in the Romualdo Member of the Santana Formation (early Cretaceous, Araripe Basin, northeast Brazil): stratigraphic, palaeoenvironmental and palaeoecological implications. Palaeogeogr Palaeoclimatol Palaeoecol 218: 145-160.

GRIMALDI D AND ENGEL MS. 2005. Evolution of the Insects. Part of Cambridge Evolution Series, $265 \mathrm{~b} / \mathrm{w}$ illus. 400 colour illus. 
HEADS SW AND MARTINS NETO RG. 2007. Orthopterida: grasshoppers, crickets, locusts and stick insects in: The Crato Fossil Beds of Brazil: Window into an Ancient World, p. 265-283.

HIRAYAMA R. 1998. Oldest known sea turtle. Nature 392: 705-707.

KELLNER AWA. 1984. Ocorrência de uma mandíbula de pterosauria (Brasileodactylus araripensis, nov. gen.; nov. sp.) na Formação Santana, Cretáceo da Chapada do Araripe, Ceará, Brasil. $33^{\circ}$ Congresso Brasileiro de Geologia, Anais 2: 578-590.

KELLNER AWA. 1987. Ocorrência de um novo crocodiliano no Cretáceo Inferior da Bacia do Araripe, Nordeste do Brasil. An Acad Bras Cienc, Rio de Janeiro 59: 219-232.

KELLNER AWA. 1999. Short note on a new dinosaur (Therapoda, Coelurosauria) from the Santana Formation (Romualdo Member, Albian), northestern Brazil. Bol Mus Nac Geol (ser. Geologia) 49: 1-8.

KELLNER AWA. 2002. Membro Romualdo da Formação Santana, Chapada do Araripe, CE - Um dos mais importantes depósitos fossíliferos do Cretáceo brasileiro. In: Schobbenhaus $\mathrm{C}$ et al. (Eds), Sítios Geológicos e Paleontológicos do Brasil, DNPM/CPRM/SIGEP, p. 121-130.

KELLNER AWA AND CAMPOS DA. 1986. Primeiro registro de amphibia (Anura) do Cretáceo Inferior da Bacia do Araripe, Nordeste do Brasil. An Acad Bras Cienc 58(4): 610.

KELLNER AWA AND TOMIDA Y. 2000. Description of a new species of Anhangueridae (Pterodactyloidea) with comments on the pterosaur fauna from the Santana Formation (Aptian-Albian), northeastern Brazil. National Science Museum Monographs, Tokyo 17: 1-135.

LIMA FJ, SARAIVA AAF AND SAYÃO JM. 2012. Revisão da Paleoflora das Formações Missão Velha, Crato e Romualdo, Bacia do Araripe, Nordeste do Brasil. Estudos Geológicos 22: 99-115.

LEE SW. 2011. A revision of the orders Blattaria, Mantodea and Orthoptera (Insecta) from the Lower Cretaceous Crato Formation of Northeast Brazil. der MathematischNaturwissenschaftlichen Fakultät der Eberhard Karls Universität Tübingen zur Erlangung des Grades eines Doktors der Naturwissenschaften (Dr. rer. nat.), 251 p.

MAISEY JG. 1991. Santana Fossils: An Illustrated Atlas. New Jersey: T.F.H. Publications, Neptune City, 459 p.

MARTILL DM, CRUICKSHANK ARI, FREY E, SMAL PG AND CLARKE M. 1996. A new crested maniraptoran dinosaur from the Santana Formation (lower cretaceous) of Brazil. J Geol Soc, London 153: 5-8.

MARTINS NETO RG. 1987. A paleoentomofauna Brasileira: estagio actual do conhecimento. Anais 10th Congresso Brasileiro Paleontologia, Rio de Janeiro II: 567-591.

MARTINS NETO RG. 1991. Sistemática dos Ensifera (Insecta, Orthopteroida) da formação Santana, Cretáceo Inferior do Nordeste do Brasil. Acta Geol Leopold 14(32): 5-160.
MARTINS NETO RG. 2005. Estágio Atual da Paleoartropodologia Brasileira: Hexápodes, Miriápodes, Crustáceos (Isopoda, Decapoda, Eucrustacea e Copepoda) e Quelicerados. Arq Mus Nac, Rio de Janeiro 63(3): 471-494.

MARTINS NETO RG. 2006. Insetos fósseis como bioindicadores em depósitos sedimentares: um estudo de caso para o cretáceo da Bacia do Araripe (Brasil). Rev Bras Zoocienc, UFJF 8(2): 159-180.

NAISH D, MARTILL DM AND FREY E. 2004. Ecology, systematics and biogeographical relationships of dinosaurs, including a new theropod, from the Santana Formation (?Albian, Early Cretaceous) of Brazil. Hist Biol 16: 57-70.

OLIVEIRA GR AND KELLNER AWA. 2005. First occurrence of Araripemys barretoi Price, 1973 in the Crato Member, Santana Formation (Early Cretaceous) northeastern Brazil. Boletim de Resumos/ II Congresso Latino-Americano de Paleontologia de Vertebrados, Museu Nacional, Rio de Janeiro 2: 193.

PINHEIRO AP, SARAIVA AAF AND SANTANA W. 2013. Shrimps from the Santana Group (Cretaceous: Albian): new species (Crustacea: Decapoda: Dendrobranchiata) and new record (Crustacea: Decapoda: Caridea). An Acad Bras Cienc 86: 663-670.

PRICE LI. 1959. Sobre um crocodilídeo notosúquio do Cretácico Brasileiro. Boletim do Departamento Nacional de Produção Mineral, Divisão de Geologia e Mineralogia, Rio de Janeiro 188: 5-55.

SARAIVA AAF, HESSEL MH, GUERRA NC AND FARA E. 2007. Concreções Calcárias da Formação Santana, Bacia do Araripe: Uma Proposta de Classificação. Estudos Geológicos 17(1): 40-57.

SARAIVA AAF, RODRIGUES SRG AND KELLNER AWA. 2003. Partes vegetativas de carófitas fossilizadas no Membro Romualdo (Albiano, Formação Santana), Bacia do Araripe, nordeste brasileiro. Bol Mus Nac, Rio de Janeiro 70: 5-8.

RENTZ DCF AND SU YN. 2003. Orthoptera (Grasshoppers, Locusts, Katydids, Crickets), p. 827-839. In: Resh VH and Cardé RT (Eds), Encyclopedia of Insects. Academic Press, California.

VILA NOVA BC, SARAIVA AAF, MOREIRA JKR AND SAIYÃO JM. 2011. Controlled excavations in the Romualdo Formation lagerstatte (Araripe basin, Brazil) and pterosaur diversity: Remarks based on new findings. Palaios 26: 173-179.

WELLNHOFER P. 1985. Nueu Pterosaurier aus der SantanaFormation (Apt) der Chapada do Araripe, Brasilien. Palaeontographica A187: 105-182.

WITTON MP. 2009. A new species of Tupuxuara (Thalassodromidea, Azhdarchoidea) from the Lower Cretaceous Santana Formation of Brazil, with a note on the nomenclature of Thalassodromidae. Cretaceous Res 30: 1293-1300. 